De Jure: Jurnal Hukum dan Syar'iah

Vol. 12, No. 1, 2020, h. 102-119

ISSN (Print): 2085-1618, ISSN (Online): 2528-1658

DOI: http://dx.doi.org/10.18860/j-fsh.v12i1.7580

Available online at http://ejournal.uin-malang.ac.id/index.php/syariah

\title{
Hak Ijbar Wali \\ Tinjauan Maqashid Syari'ah dan Antropologi Hukum Islam
}

\author{
Muhammad Ngizzul Muttaqin \\ IAIN Tulungagung \\ muttaqinizzu119@gmail.com \\ Nur Fadhilah \\ IAIN Tulungagung \\ nurfafiyalana@gmail.com
}

\begin{abstract}
:
As an act determined by religion, marriage is a very sacred act, both in terms of religion and from the agreement between the husband and the wife. The sacredness in marriage certainly cannot be tainted by various aspects. Provisions regarding ijbar rights for the guardians need to be reviewed in terms of their relevance to maintain the holiness of marriage. In its way, the execution of ijbar rights has implications for the wife's unwillingness. Whereas, the purpose of the application of Islamic law is to create justice and peace for humanity. Even from the community, the rules regarding the ijbar rights held by the guardians met pros and municipality. As literature-based research through extensive library studies, this paper attempts to reconcile the legal issues of ijbar rights from the viewpoint of the legal objectives (maqashid shari'a) and the conditions of culture and the culture of society (the anthropology of Islamic law). The findings in this study are: In the perspective of maqashid shari'ah, the practice of ijbar wali's right does not bring the basic principles of maqashid shari'ah. Namely the principle in creating happiness of calm, and peace in marriage, whereas in the anthropological perspective of Islamic law. The practice of rights ijbar guardian cannot be justified in the social sphere of society, confinement and restraints on women in the practice of ijbar rights are not in accordance with the current socio-cultural of society. So that the practice of ijbar rights cannot be accepted by the community.
\end{abstract}

Keywords: Ijbar rights; maqashid shari'ah; anthropology of Islamic law.

\section{Abstrak:}

Sebagai perbuatan yang ditetapkan oleh agama, perkawinan merupakan perbuatan yang sangat sakral, baik dari segi agama, maupun dari sudut pandang perjanjian antara suami dan istri. Sakralitas dalam perkawinan tentu tidak bisa dinodai oleh berbagai aspek. Ketentuan tentang hak ijbar bagi wali, perlu dikaji kembali relevansinya guna menjaga sakralitas dalam perkawinan. Pelaksanaan hak ijbar berimplikasi pada ketidak relaan sang istri. Padahal, 
tujuan dari pemberlakuan hukum Islam adalah untuk menciptakan keadilan dan ketentraman bagi umat manusia. Dalam sudut pandang masyarakat pun, ketentuan mengenai hak ijbar yang dimiliki oleh wali menemui pro dan kontra. Sebagai penelitian berbasis litteratur melalui studi pustaka yang ekstentif, tulisan ini berupaya menyelaraskan kembali problematika hukum hak ijbar ditinjau dari sudut pandang tujuan hukum (maqashid syari'ah) dan kondisi kultur dan budaya masyarakat (antropologi hukum Islam). Temuan dalam penelitian ini adalah: dalam perspektif maqashid syari'ah, praktik hak ijbar wali tidak mendatangkan prinsip-prinsip dasar maqashid syari'ah, yaitu prinsip dalam menciptakan kebahagiaan, ketenangan, dan ketentraman dalam perkawinan, sedangkan dalam perspektif antropologi hukum Islam, praktik hak ijbar wali tidak bisa dibenarkan dalam ranah sosial masyarakat, keterkungkungan dan pengekangan terhadap perempuan dalam praktik hak ijbar tidak sesuai dengan sosio kultural masyarakat saat ini, sehingga praktik hak ijbar ini tidak bisa diterima oleh masyarakat.

Kata Kunci: hak ijbar; maqashid syari'ah; antropologi hukum Islam.

\section{Pendahuluan}

Perkawinan merupakan syariat Islam yang digunakan sebagai sarana sah bagi laki-laki dan perempuan untuk membentuk keluarga. Selain mencari ridha Allah, pernikahan juga bertujuan menyalurkan hasrat seksual, melanjutkan keturunan, mencapai kebahagiaan dalam hidup. ${ }^{1}$ Berbagai cara dilakukan dilakukan untuk mencapai tujuan ini, salah satunya adalah memilih pasangan yang baik. Pada dasarnya, setiap manusia diberikan kewenangan dan kebebasan untuk memilih pasangan. Secara sosiologis, pemilihan pasangan akan memperhatikan penampilan fisik, keturunan, dan finansial. Dalam kata lain, sebelum melaksanakan perkawinan, seseorang harus mempertimbangkan bibit, bebet, dan bobot dari calon pasangannya. $^{2}$ Meskipun demikian, Rasulullah saw. memberikan penekanan bahwa aspek agama menjadi kunci utama dalam pemilihan pasangan hidup guna mencapai kebahagiaan hakiki. ${ }^{3}$

Kebebasan memilih calon pasangan dalam praktiknya tidak jarang terhalang oleh hak ijbar yang dimiliki oleh orang tua atau wali dari calon mempelai perempuan. Pada dasarnya, hak ijbar dipandang sebagai wujud perlindungan dan kasih sayang orang tua terhadap anak perempuan. Meskipun demikian, dalam praktiknya tidak jarang hak ijbar dimaknai dengan pemaksaan kehendak terhadap anak perempuan pada saat pemilihan pasangan. ${ }^{4}$ Konsep hak ijbar dinilai telah mendiskriminasikan kaum perempuan, serta bertentangan dengan prinsip

\footnotetext{
1 Ahmad Atabik dan Khoridatul Mudhiiah, "Pernikahan Dan Hikmahnya Perspektif Hukum Islam," YUDISIA : Jurnal Pemikiran Hukum dan Hukum Islam 5, no. 2 (2014): 286.

${ }^{2}$ Safrudin Aziz, "Tradisi Pernikahan Adat Jawa Keraton Membentuk Keluarga Sakinah," IBDA : Jurnal Kajian Islam dan Budaya 15, no. 1 (2 Mei 2017): 29, https://doi.org/10.24090/ibda.v15i1.724.

${ }^{3}$ Nurun Najwah, "Kriteria Memilih Pasangan Hidup (Kajian Hermeneutika Hadis)," Jurnal Studi Ilmu-Ilmu Al-Qur'an Dan Hadis 17, no. 1 (8 Mei 2018): 106, https://doi.org/10.14421/qh.2016.170105 .

${ }^{4}$ Muhammad Lutfi Hakim, "Rekonstruksi Hak Ijbar Wali: Aplikasi Teori Perubahan Hukum dan Sosial Ibn al-Qayyim Al-Jawziyyah," Al-Manahij: Jurnal Kajian Hukum Islam 8, no. 1 (2014): 46, https://doi.org/10.24090/mnh.v8i1.401.
} 
keadilan..$^{5}$ Dengan hak ijbar ini, wali perempuan punya kewenangan untuk menikahkan anak perempuannya tanpa mendapatkan persetujuan dari yang bersangkutan. Model semacam ini dikenal dengan istilah "kawin paksa". ${ }^{6}$ Fenomena pemaksaan dalam dalam tradisi masyarakat tertentu telah mengakar kuat. Terlebih argumentasi mereka disandarkan pada pandangan ulama' madzhab syafi'i yang membenarkan praktik hak ijbar. Pemahaman Imam Syafi'i mengenai hak ijbar dinisbatkan pada hadits yang meriwayat tentang perkawinan 'Aisyah dengan Rasulullah saw. ${ }^{7}$

Tradisi kawin paksa dapat mengancam keutuhan rumah tangga. Tidak jarang perkawinan yang dilandaskan pada keterpaksaan berakhir pada perceraian. Angka perceraian di Indonesia mengalami peningkatan setiap tahun. Pada tahun 2017 pengadilan agama se-Indonesia memutus 380.723 kasus perceraian. ${ }^{8}$ Sedangkan pada tahun 2018 memutus 443.645 kasus perceraian. ${ }^{9}$ Beberapa riset menunjukkan bahwa, salah satu faktor pendorong terjadinya perceraian adalah kawin paksa. ${ }^{10}$ Tujuan perkawinan yaitu terciptanya keluarga bahagia dan kekal juga tidak dapat dipenuhi. Kondisi ini dapat berpengaruh terhadap kesehatan mental suami, istri, dan bahkan anak-anak. ${ }^{11}$

Hak ijbar telah dibahas dalam fiqh klasik. Namun dalam perkembangannya, para ulama mulai melakukan kajian kembali tentang hak ijbar. Salah satu pendekatan yang digunakan adalah maqashid syari'ah. Fathi al-Daroini menyatakan bahwa hukum Islam bertujuan menciptakan kemaslahatan, keadilan, ketentraman bagi umat Islam. ${ }^{12}$ Pendekatan maqashid syari'ah dianggap dapat menyelesaikan problematika kontemporer. Pendekatan ini dipandang memiliki adabtabilitas yang tinggi dengan kondisi dan realitas sosial yang terjadi saat ini. ${ }^{13}$ Selain itu, penatapan hukum Islam juga tidak dapat dipisahkan dari aras sosiologis. Hukum Islam tidak jarang merupakan respon terhadap kondisi empiric yang terjadi di masyarakat. Hukum timbul dari suatu sistem kemasyarakatan yang terus mengalami perubahan

\footnotetext{
5 Husnul Haq, "Reformulasi Hak Ijbar Fiqhi Dalam Tantangan Isu Gender Kontemporer," PALASTREN Jurnal Studi Gender 8, no. 1 (30 Maret 2016): 215, https://doi.org/10.21043/palastren.v8i1.941.

${ }^{6} \mathrm{Haq}, 218$.

7 Syaiful Hidayat, "Hak Ijbar Wali Nikah Dalam Kajian Historis Fiqh Shâfi'̂̂," Tafáqquh: Jurnal Penelitian Dan Kajian Keislaman 3, no. 1 (1 Juni 2015): 1.

${ }^{8}$ Mahkamah Agung RI, Laporan Tahunan Mahkamah Agung Republik Indonesia Tahun 2017 (Jakarta: Mahkamah Agung, 2018), 55.

${ }^{9}$ Mahkamah Agung RI, Laporan Tahunan Mahkamah Agung Republik Indonesia Tahun 2018: Era Baru Peradilan Modern Berbasis Teknologi Informasi (Jakarta: Mahkamah Agung, 2019), 114.

${ }^{10}$ Isnawati Rais, "Tingginya Angka Cerai Gugat (khulu') Di Indonesia: Anlisis Kritis Terhadap Penyebab Dan Altternatif Solusi Mengatasi," Al-Adalah 12, no. 1 (Juni 2014): 197; Maimun Maimun, Mohammad Toha, dan Misbahul Arifin, "Fenomena Tingginya Angka Cerai-Gugat Dan Faktor Penyebabnya: Analisis Reflektif Atas Kasus-Kasus Perceraian Di Madura," Islamuna: Jurnal Studi Islam 5, no. 2 (12 April 2019): 163, https://doi.org/10.19105/islamuna.v5i2.2105.

11 Suardiman, "Kehidupan Perkawinan Bahagia: Dampak Positif Untuk Keseimbangan Mental Anak Kini Dan Nanti," Buletin Psikologi 6, no. 2 (23 September 2015): 49, https://doi.org/10.22146/bpsi.7397.

${ }^{12}$ Fathi al-Daroini, Al-Manahij al-Ushuliyyah fi Ijtihad bi al-Ra'yi fi al-Tasyri' (Damaskus: Dar al-Kitab al-Hadis, 1975), 28.

${ }^{13}$ Abu Zahrah, Ushul Fiqh al-Islam, Jilid II, (Beirut: Dar al-Fikr al-Muassir, 1986), Abu Zahrah, Ushul Fiqh al-Islam, vol. II (Beirut: Dar al-Fikr al-Muassir, 1986), 369-70.
} 
dan dinamika sosial. ${ }^{14}$ Seiring dengan perkembangan ilmu hukum, antropologi hukum diperlukan guna mempelajari hukum dari konteks kondisi dan kultur masyarakat, ${ }^{15}$ artinya hukum bukan hanya sebagai doktrin, akan tetapi hukum menjadi suatu budaya yang diterima dikalangan masyarakat secara keseluruhan.

Dalam permasalahan hukum hak ijbar harus melewati proses adaptasi dan penerimaan di masyarakat. Adakah pertentangan di masyarakat terkait hal ini? Apakah hak ijbar selaras dengan tujuan hukum Islam? Berdasarkan persoalan di atas, artikel ini bertujuan mendeskripsikan hak ijbar ditinjau dari maqashid shari'ah. Selain itu artikel ini melakukan kajian hak ijbar perspektif antropologi hukum. Artikel ini berasal dari penelitian kepustakaan. sumber data dari penelitian ini diambil dari kitab-kitab maupun buku-buku yang berkaitan dengan fiqh munakahah, maqashid syari'ah, antropologi hukum

\section{Hak Ijbar Wali Pada Anak Perempuan}

Perwalian secara etimologi berarti cinta dan pertolongan, atau berarti kekuasaan dan kemampuan. Secara terminologi, perwalian adalah kemampuan seseorang untuk melakukan suatu tindakan (tasharuf) tanpa adanya izin dari orang lain. ${ }^{16}$ Sedangkan wali secara umum adalah seseorang yang karena kedudukannya berwenang untuk bertindak terhadap dan atas nama orang lain. Dalam pernikahan, wali adalah seseorang yang bertindak atas nama mempelai perempuan dalam suatu akad nikah. Seseorang berhak menjadi wali jika memenuhi syarat-syarat ini: Pertama, Islam. Tidak sah orang non muslim menjadi wali nikah untuk perempuan muslimah. Kedua, adil. Adil berarti tidak pernah terlibat dengan dosa besar dan tidak sering terlibat dengan dosa kecil, serta tetap memelihara sopan santun (muru'ah).

Ketiga, laki-laki. Perempuan tidak boleh menjadi wali. Ulama madzhab Hanafi mempunyai pendapat yang berbeda dalam persyaratan ini. Menurut mereka, perempuan yang sudah dewasa dan berakal sehat dapat menjadi wali untuk dirinya sendiri dan dapat pula menjadi wali untuk perempuan lain. Keempat, telah dewasa dan berakal sehat, dalam arti anak kecil atau orang gila tidak berhak menjadi wali. Kelima, tidak berada dalam pengampuan (mahjur alaih), sebab orang yang berada di bawah pengampunan tidak dapat berbuat hukum dengan sendirinya, padahal kedudukannya sebagai wali merupakan suatu tindakan hukum. Keenam, tidak sedang melakukan ihram, baik ihram umrah maupun haji. Dalam hal ini, ulama mazhab Hanafi berpendapat bahwa wali yang sedang ihram boleh menikahkan pasangan yang sedang ihram. Ketujuh, berpikiran baik. Orang yang terganggu pikirannya karena ketuaan misalnya tidak boleh menjadi wali, karena dikhawatirkan tidak akan mendatangkan maslahah dalam pernikahan tersebut. ${ }^{17}$

Wali bagi seorang perempuan dapat diklasifikasikan menjadi dua kelompok, yaitu: wali nasab atau wali yang yang berhubungan tali kekeluargaan dengan perempuan yang akan menikah, dan wali hakim atau orang yang menjadi wali

\footnotetext{
${ }^{14}$ Dedi Sumanto, "Hukum Adat Di Indonesia Perspektif Sosiologi Dan Antropologi Hukum Islam," JURIS (Jurnal Ilmiah Syariah) 17, no. 2 (31 Desember 2018): 182, https://doi.org/10.31958/juris.v17i2.1163.

${ }^{15}$ J.B Daliyo, Pengantar ilmu hukum (Jakarta: Gramedia, 2009), 139.

${ }^{16}$ Wahbah al-Zuhaili, al-Fiqh al-Islami wa Adillatuh (Damaskus: Dar al Fikr, 2003), 6690.

${ }_{17}$ Mushtafa al-Khin, Musthafa al-Bugha, dan Ali al-Syarbaji, Al-Figh al-Manhaji 'ala madzhabi alImam al-Syafi'i (Damaskus: Dar al-Qalam, 2005), 59-60.
} 
dalam kedudukannya sebagai hakim atau penguasa. ${ }^{18}$ Secara urutan, orang yang berhak menjadi wali nikah adalah: ayah, kakek (bapaknya bapak), saudara laki-laki kandung, saudara laki-laki seayah, anak laki-laki saudara kandung, anak laki-laki saudara seayah, paman sekandung, paman seayah, anak laki-laki paman sekandung, anak laki-laki paman seayah, keluarga yang mendapatkan bagian ashabah. Jika tidak ada maka beralih ke wali hakim. ${ }^{19}$

Berdasarkan hak yang dimilikinya, wali dari perempuan dibagi menjadi dua yaitu wilayah ijbar dan wilayah ikhtiyar. Wilayah ijbar adalah hak yang dimiliki wali untuk menikahkan orang yang ada di bawah perwaliannya tanpa harus terlebih dahulu meminta persetujuan darinya, dan pernikahan itu dianggap sah, sehingga tidak boleh ditentang oleh siapa pun. Orang yang memiliki hak ini disebut wali mujbir. Semua ulama dari berbagai madzhab sepakat bahwa hak ini berlaku bagi anak kecil, baik laki-laki maupun perempuan, serta orang gila, baik laki-laki atau perempuan. Kemudian mereka berbeda pendapat tentang anak perempuan yang masih perawan, dewasa, dan berakal, di mana ulama madzhab Hanafi tidak memberlakukan hak ijbar atas anak perempuannya, sementara jumhur ulama memberlakukan hak ijbar atas anak perempuannya, sebagaimana memberlakukan hak ijbar atas perempuan yang belum dewasa. ${ }^{20}$

Wali mujbir yang berhak mengawinkan tanpa seizin putrinya adalah ayah dan kakek, dengan kepentingan yang terbaik untuk putrinya. Wali mujbir ini bisa dilakukan dengan syarat: putrinya dinikahkan dengan laki-laki sekufu; menggunakan mahar misil; tidak dinikahkan dengan laki-laki yang mengecewakan; tidak terdapat konflik antara wali dan calon suami maupun putrinya; calon mempelai perempuan tidak mengikrarkan bahwa dia tidak perawan. Ijbar dalam perwalian berbeda definisi dengan ikrah. Kalau ikrah berarti paksaan secara mutlak, namun ijbar lebih condong ke rasa tanggung jawab dan keinginan untuk memberikan yang terbaik. Meskipun hakikat keduanya sama, namun unsur memaksa dalam ijbar memiliki maksud dan tujuan yang baik sehingga hukum islam memperbolehkan. Berbeda dengan ikrah yang sangat dilarang dalam Islam. ${ }^{21}$

Perbedaan ini muncul karena adanya perbedaan mengenai illat (alasan) adanya hak ijbar. Ulama madzhab Maliki, Syafi'i, Hambali, Atha', Sya'bi, dan An Nakha'i mengatakan bahwa illat hak ijbar adalah keperawanan (al-bakarah), karenanya hak ijbar berlaku bagi anak perempuan yang masih perawan, baik sudah dewasa atau belum. Sementara ulama madzhab Hanafi, Ibnu Taimiyah, dan Ibnu Qayyim menegaskan, illat (alasan) hak ijbar adalah belum dewasa (shigar), sehingga hak ijbar hanya berlaku bagi anak perempuan yang belum dewasa, dan tidak berlaku bagi perempuan yang sudah dewasa (baligh). ${ }^{22}$

Adapun wilayah ikhtiyar adalah hak yang dimiliki wali untuk menikahkan orang yang ada di bawah perwaliannya tetapi harus ada persetujuan dari orang tersebut. Hak ini menurut kesepakatan ulama, berlaku bagi janda, karenanya tidak ada satu pun wali berhak memaksanya menikah tanpa adanya persetujuan darinya,

\footnotetext{
18 Amir Syarifuddin, Hukum Perkawinan Islam Di Indonesia: Antara Fiqh Munakahat Dan UndangUndang Perkawinan (Jakarta: Kencana, 2006), 75.

${ }^{19}$ al-Khin, al-Bugha, dan al-Syarbaji, Al-Fiqh al-Manhaji 'ala madzhabi al-Imam al-Syafi'i, 59.

${ }^{20}$ al-Zuhaili, al-Fiqh al-Islami wa Adillatuh, 6690.

${ }^{21}$ Arini Rabbi Izzati, "Kuasa Hak Ijbar Terhadap Anak Perempuan Perspektif Fiqh dan HAM," AlMawarid: Jurnal Hukum Islam 11, no. 2 (2011): 116.

${ }^{22}$ Ibnu Rusyd, Bidayah al-Mujtahid wa Nihayah al-Muqtashid, vol. 2 (Beirut: Dar al-Fikr, 2005).
} 
sebab janda faham akan maksud pernikahan dan sudah pengalaman dalam hal itu, maka tidak boleh dipaksa menikah. Sedangkan bagi perempuan selain janda, para ulama berbeda pendapat. Secara umum bisa dikatakan, perempuan yang tidak masuk dalam kategori hak ijbar, masuk dalam kategori hak ikhtiyar. ${ }^{23}$

\section{Maqashid Syari'ah: Menciptakan Maslahah, Keadilan, dan Ketentraman}

Tujuan hukum Islam sering disebut dengan maqashid al-syari'ah yang diaktualisaikan melalui pencerminan nilai-nilai fundamental dalam hukum Islam, yakni memelihara agama, jiwa, nalar, keturunan, harta, kehormatan dan lingkungan. ${ }^{24}$ Secara linguistik. maqashid diterjemahkan dengan berbagai istilah, yakni maqashid al-syari', maqashid al-syari'ah, dan al-maqashid al-syar'iyah. ${ }^{25}$ Prinsip umum dari maqashid al-syari'ah adalah menegaskan pentingnya menciptakan kemaslahatan, ketentraman, dan menolak kemadharatan. Dalam hal ini al-Raysunî berkata sebagai berikut:

$$
\begin{aligned}
& \text { المقاصد العامة : حفظ النظام وجلب المصالح ودرء المفاسد و إقامة المساو اة بين الناس وجعل الثريعة مهابة مطاعة الثابة }
\end{aligned}
$$

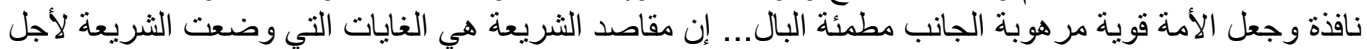

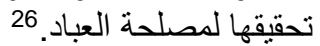

"Maqashid secara umum adalah memelihara aturan, menarik kemaslahatan, menolak kerusakan, menegakkan persamaan di antara umat manusia dan menjadikan syarî'ah (hukum Islam) sebagai suatu hukum yang berwibawa, dan ditaati. Di sisi lain, dapat menjadikan umat sebagai (komunitas) yang kuat (berkualitas) lagi disegani dan menenangkan... Jadi, sesungguhnya maqashid al-syari'ah itu merupakan tujuan ditetapkannya hukum Islam untuk direalisasikannya demi kepentingan umat secara keselluruhan."

Dalam kajian maqashid diharapkan dapat melahirkan suatu perspektif penalaran hukum Islam yang tidak hanya berkutat pada ketentuan-ketentuan litereratur suatu teks (dhahir nash), tetapi juga memberi perspektif penalaran hukum Islam yang senantiasa mampu berdialog dengan perkembangan zaman dengan perbagai problematika aktualnya. Menurut Khalid Mas'ud, upaya menandaskan maslahah sebagai essensi terpenting dari tujuan-tujuan hukum. ${ }^{27}$ Selama ini, klasifikasi maqashid identic dengan pembagian maqashid dharuriyat, maqashid hajiyat, dan maqashid tahsiniyat, maqashid sebagai bukti perwujudan serta hirarki kemaslahatan yang harus ada bagi manusia. Dalam rangka menjaga keberlangsungan dinamika hukum Islam, pengkategorian maqashid juga perlu

\footnotetext{
${ }^{23}$ al-Zuhaili, al-Fiqh al-Islami wa Adillatuh, 6690.

${ }^{24}$ Maqashid al-syari'ah merupakan tema penting dalam diskursus pemikiran hukum Islam, hal ini ditandai dengan maraknya kajian maqashid yang dilakukan oleh beberapa ulama' masa sahabat sampai saat ini. Malik bin Anas misalnya, telah menawarkan premis mayornya tentang maslahah sebagai ruh dari hukum Islam. Kemudian al-Imam al-Juwayni (w. 478 H), al-Ghazali (w. 505 H), alRazi (w. 606 H), al-Amidi (w. $631 \mathrm{H}$ ), al-'Izz bin 'Abd al-Salam (w. $631 \mathrm{H}$ ), al-Qarafî (w. 685 H), alThufî (w. 716 H), Ibn Taymiyyah (w. 728 H), (w. 751 H), al-Syathibi (w. 790 H), Ibn 'Asyur (w.1393 H), Jamaluddin Atiyah dan alal al-Fasi dan yang paling mutakhir adalah konsep ulama' kontemporer seperti Yusuf al-Qaradawi dan Jaser Audah.

${ }^{25}$ Ahmad al-Raysuni, Nazhariyat al-Maqashid 'Inda al-Imam al-Syathibi (Riyadh: al-Dar al-'Alamiyah li al-Kitab al-Islami wa al-Ma'had al-'Alami al-Fikr al-Islami, 1981), 13-17.

${ }^{26}$ al-Raysuni, 18-19.

${ }^{27}$ Muhammad Khalid Mas'ud, Filsafat Hukum Islam Dan Perubahan Sosial, trans. oleh Yudian W. Aswin (Surabaya: Al-Ikhlas, 1987), 233.
} 
dilihat dalam sudut pandang lain, yakni duniawi dan ukhrawi. al-masalih aldunyawiyyah dapat diidentifikasi dengan maqashid al-tabi'ah dan al-masalih alukhrawiyah dapat diidentifikasikan dengan maqasid al-asliyyah. Yang harus dicatat adalah bahwa klasifikasi ini tidak dimaksudkan untuk menarik garis pemisah secara tajam antara dua orientasi kandungan hukum Islam itu, sebab keduanya secara hakiki tidak dapat dipisahkan dalam hukum Islam. ${ }^{28}$ Kedua klasifikasi di atas diharapkan menjadi lokomotif ijtihad. Dalam perspektif para mujtahid, hal ini difahami sebagai batas majal al-ijtihad.

Problem mendasar ketika hukum Islam hendak diposisikan pada tataran yang lebih progresif dan dinamis adalah problem metodologi. Pada problem ini, ushul fiqh sebagai landasan teoritik bangunan pemikiran hukum Islam, terjebak pada pergulatan kaidah-kaidah bahasa, seolah-olah para pakar yang terlibat dalam pergaulan itu sedang mencoba untuk memahami nash yang di dalamnya ada pikiran Tuhan. Inilah tedapat paradoks yang sulit dimengerti. Bagaimana pikiran Tuhan difahami pada tataran bahasa yang notabene adalah ciptaan manusia. Pertanyaan filosofis lebih lanjut adalah apakah hukum Islam yang bersumber kepada kemaslahatan harus sesuai dengan mashlahahnya Tuhan? Bukankah ukuran kemaslahatan itu ada di bumi, karena pada hakekatnya manusia yang merasakan sesuatu itu maslahah atau bukan?

Pada intinya, pembaharuan hukum islam ulama' kontemporer membutuhkan reviitalisasi ushul figh, agar tidak terjebak pada kungkungan ushul fiqh klasik yang language-oriented, tetapi mengabaikan fakta-fakta empirik di lapangan. Pendekatan ushul figh yang lebih condong ke deduktif, misalnya diorientasi kepada pendekatan induktif dan empiris yang lebih dekat pada problem-problem riel masyarakat, bukan masyarakat yang terus menerus dipaksa sesuai dengan teks.

Masdar Farid Mas'ud sebagai salah satu pemikir muslim Indonesia yang menempatkan kemaslahatan dan keadilan sebagai landasan syari'at, baik landasan filosofi maupun epistimologinya. Masdar berpendapat bahwa hukum (legal) haruslah didasarkan kepada sesuatu yang tidak disebut hukum. ${ }^{29}$ Akan tetapi didasarkan kepada yang lebih mendasar dari sekedar hukum, yaitu sebuah sistem nilai yang dengan sadar diambil sebagai sebuah keyakinan yang harus diperjuangkan, yakni kemaslahatan, keadilan. ${ }^{30}$

Dengan demikian menjadi jelas bahwa yang fundamental dari bangunan pemikiran hukum Islam (fiqh) adalah kemaslahatan. Kemaslahatan manusia yang universal atau dalam ungkapan yang lebih operasional, keadilan sosial. Karena sejak semula, syariat Islam tidak memiliki basis (tujuan) lain kecuali kemaslahatan manusia. Ungkapan standart bahwa syari'at Islam dicanangkan demi kebahagiaan manusia lahir batin, duniawi maupun ukhrawi, semuanya mencerminkan prinsip kemaslahatan.

\footnotetext{
${ }^{28}$ Keterkaitan orientasi kandungan hukum Islam merupakan perbedaan hakiki hukum Islam dengan hukum-hukum buatan manusia, yang tidak bersumber kepada wahyu. Perbedaan ini disebut oleh Abdullah Nasih Ulwan sebagai perbedaan prinsip (Al-Rabbaniyyah). Abdullah Nashih Ulwan, Islam Syariat Abadi, trans. oleh Daud Rashid (Jakarta: Usamah Press, 1992), 69-70.

${ }^{29}$ Hukum di sini maksudnya adalah ayat-ayat Al-Qur'an dan Hadis-Hadis Nabi yang pada dasarnya adalah ayat dan hadis hukum.

${ }^{30}$ Masdar Farid Mas'udi, "Meletakkan Kembali Mashlahah sebagai Acuan Syari'at," Ulumul Qur'an 6, no. 3 (1995): 93.
} 
Munawir Syadzali dan Ali Yafie memandang bahwa ketentuan-ketentuan dalam bidang mu'amalah terbuka kesempatan bagi pemikiran atau penalaran intelektual dalam mencari pelaksanaan syariat dengan kepentingan dan prinsip keadilan sebagai dasar pertimbangan dan tolok ukur utama. Karena, aspek muamalah diberikan oleh nash dalam bentuk ketentuan yang bersifat umum, yang dapat dikembangkan lebih lanjut guna mewujudkan kemaslahatan dan menegakkan ketertiban dalam pergaulan masyarakat serta menjamin hak dan kewajiban yang berkepentingan secara adil. ${ }^{31}$ Lebih dari itu, maqashid syari'ah mempunyai esensi berupa menciptakan kemaslahatan, baik kemaslahatan yang bersifat pribadi, maupun kemaslahatan yang bersifat umum. ${ }^{32}$

Dalam pembahasan wali mujbir, Sahal Mahfud berpendapat bahwa inti dari ketentuan tersebut adalah adanya kemaslahatan. Beliau memandang tidak perlu mengedepankan pendapat yang menganggap wali mujbir masih relevan atau pendapat sebaliknya. Beliau menempatkan pendapat-pendapat tersebut hanya sebagai opsi yang intinya adalah demi kemaslahatan, baik kemaslahatan bagi perempuan calon mempelai ataupun kemaslahatan keluarga calon mempelai secara umum. ${ }^{33}$

\section{Antropologi Hukum Islam: Mempertemukan Hukum Islam dan Realitas Sosial}

Istilah modern secara bahasa berarti baru, kekinian, akhir, up to date atau semacamnya. Bisa dikatakan sebagai lawan dari lama, kolot atau semacamnya. ${ }^{34}$ Modernisasi memang sangat luas artinya, mencakup proses memperoleh citra (images) baru seperti citra tentang arah perubahan atau citra tentang kemungkinan perkembangan. Batasan-batasan modernisasi seringkali hanya ditekankan pada aspek-aspek perubahan di bidang teknologi dan ekonomi. Akan tetapi, sebagaimana dikemukakan oleh Manfred Halpern, revolusi modernisasi sebenarnya melibatkan transsformasi semua item yang berlaku sebelumnya dalam masyarakat, baik sistem politik, sosial, ekonomi, intelektual, keagamaan, maupun psikologi. ${ }^{35}$

Perdebatan di antara beberapa kelompok di atas bukanlah tentang pokokpokok ajaran agama itu sendiri (great tradition), melainkan bagaimana memanifestasikan ajaran Islam itu di dalam sistem kehidupan sosial (little tradition). ${ }^{36}$ Sebab, perubahan masyarakat dalam berbagai aspeknya baik ekonomi, politik, sosial, budaya dan sebagainya harus direspon oleh hukum

\footnotetext{
31 Ali Yafie, "Posisi Ijtihad dalam Keutuhan Ajaran Islam," dalam Ijtihad dalam sorotan, ed. oleh Jalaluddin Rahmat (Bandung: Mizan, 1994), 71,121.

${ }^{32}$ Muhammad Ngizzul Muttaqin dan Iffatin Nur, "Menelusuri Jejak Maqashid Syari'ah Dalam Istinbath Hukum Imam Hambali," Ahkam: Jurnal Hukum Islam 7, no. 1 (1 Juli 2019): 162, https://doi.org/10.21274/ahkam.2019.7.1.143-168.

${ }^{33}$ Mahsun Mahsun, "Wali Mujbir Dalam Pusaran Pemikiran KH. MA. Sahal Mahfudh," Al-Mabsut: Jurnal Studi Islam dan Sosial 8, no. 1 (1 April 2014): 23.

${ }^{34}$ Badri Khaeruman, "Al-Qaradawi Dan Orientasi Pemikiran Hukum Islam Untuk Menjawab Tuntutan Perubahan Sosial," Wawasan: Jurnal Ilmiah Agama Dan Sosial Budaya 1, no. 2 (15 November 2016): 227-38, https://doi.org/10.15575/jw.v1i2.740.

${ }^{35}$ Ahmad Qadri Abdillah Azizy, Melawan Globalisasi: Reinterpretasi Ajaran Islam Persiapan SDM dan Terciptanya Masyarakat Madani (Yogyakarta: Pustaka Pelajar, 2003), 8.

${ }^{36}$ Andrew Rippin, Muslims: their religious beliefs and practices, 4th ed, The library of religious beliefs and practices (New York: Routledge, 2011), 19.
} 
Islam di tengah kehidupan masyarakat, sebagai pengendalian sosial (sosial engineering) dan kesejahteraan sosial (sosial welfare). ${ }^{37}$ Dengan funsi-fungsi ini, diharapkan hukum Islam tidak mengalami krisis dan inefektivitas hukum di tengah kehidupan masyarakat yang makin kompleks.

Hukum Islam sebagai norma etik adalah produk pemikiran ilmiah kaum mujtahid. Sebagai hasil dari analisis ilmiah, hukum Islam tentu tidak bisa dilepaskan dari cara berfikir logis dan empiris. Karenanya, dalam kajian hukum Islam semua bidang keilmuan memiliki peran yang signifikan dalam upaya induktifikasi maupun deduktifikasi temuan hukum. Dalam konteks ini barangkali perlu sinergisitas sains, filsafat dan agama (teks). Hal ini mutlak diperlukan untuk membangun hukum islam yang responsif di era modern, khususnya dalam membuat rumusan baru sebagai metodologi hukum islam. Integrasi ilmu (sosiologi/kemanusiaan) dan agama (teks) tidak dapat dipungkiri lagi keberadaannya sebagai metode indimaji (dalam bahasa al-Qardawi) untuk menjawab problematika hukum modern. Sebab, berpaku pada analisis tekstuallinguistik semata tidak cukup memadahi untuk menganalisa fenomena hukum kekinian.

Dalam studi agama dierlukan suatu wilayah yang ditunjukkan pada fenomena kehidupan beragama, manusia pada umumnya biasa didekati dengan disiplin keilmuan yang bersifat historis-empiris dan bukan doctrinal-normatif. ${ }^{38}$ Berangkat dari pemahaman seperti ini, ternyata agama memiliki banyak wajah (multiface), agama tidak lagi dipahami seperti generasi terdahulu, yakni sematamata urusan yang berkait dengan aspek ketuhanan semata, melainkan berkaitan erat dengan persoalan-persoalan historis-kultural yang juga keniscayaan manusia kehidupan manusia. Dengan kata lain, ajaran Islam memiliki dua wajah yang saling berkait, seperti: aspek ideal dan aspek aktual, aspek doktrinal dan aspek peradaban, aspek normatifitas dan aspek historisitas, aspek normatif dan aspek aktual, atau aspek teoritis dan aspek praktis. ${ }^{39}$

Antropologi hukum adalah ilmu pengetahuan yang mempelajari manusia sebagai makhluk biologis yang diatur oleh hukum-hukum biologis yang diciptakan oleh tuhan. ${ }^{40}$ Apabila dicampurkan dengan keislaman disebut dengan Antropologi Hukum Islam, di mana perubahan makna tersebut terletak pada kajian yang dilakukan, yaitu masih berkaitan dengan masyarakat muslim. Hal tersebut sesuai dengan kajian dalam antropologi hukum itu sendiri, yaitu menggali norma-norma dan nilai-nilai dalam masyarakat.

Mengkaji fenomena keagamaan berarti mempelajari perilaku manusia dalam kehidupannya beragama. Fenomena keagamaan adalah perwujudan sikap dan perilaku manusia yang berkait hal-hal yang sakral. Ilmu-ilmu sosial dengan caranya masing-masing dapat mengamati secara cermat terhadap

\footnotetext{
${ }^{37}$ Mujiyono Abdillah, Dialektika Hukum Islam Dan Perubahan Sosial: Sebuah Refleksi Sosiologis Atas Pemikiran Ibn Qayyim Al-Jauziyyah (Surakarta: Muhammadiyah University Press, 2003), 2.

${ }^{38}$ Muhammad Amin Abdullah, "Relevansi Studi Agama dalam Milenium Ketiga," dalam Mencari Islam: Studi Islam Dengan Berbagai Pendekatan, ed. oleh Muhammad Amin Abdullah dkk (Yogya: Tiara Wacana, 2000), 1.

${ }^{39}$ Cik Hasan Bisri, Model Penelitian Fiqh Jilid 1: Paradigma Penelitian Figh Dan Fiqh Penelitian (Jakarta: Kencana, 2003), 16.

40 Beni Ahmad Saebani dan Encup Supriatna, Antropologi Hukum (Bandung: CV Pustaka Setia, 2012), 71.
} 
perilaku manusia. ilmu sejarah mengamati proses terjadinya perilaku, ilmu sosiologi menyoroti posisi manusia yang membawanya kepada perilaku itu, dan antropologi memperhatikan terbentuknya pola-pola perilaku itu dalam tatanan nilai yang dianut dalam kehidupan manusia. ${ }^{41}$

Antropologi dalam memahami agama dapat diartikan salah satu upaya memahami agama dengan cara melihat wujud praktik keagamaan yang tumbuh dan berkembang dalam masyarakat. Melalui pendekatan antropologi, agama tampak akrab dan dekat dengan masalah-masalah yang dihadapi oleh manusia. pada tataran lebih praktis, melalui antropologi, kita dapat melihat agama dalam hubungannya dengan mekanisme pengorganisasian. Dalam kaitan ini dapat disimpulkan bahwa hukum Islam harus mampu berdialog dengan kondisi dan pola perilaku masyarakat. ${ }^{42}$

Dalam kajian antropologi, produk hukum merupakan sebuah bagian integral dari kebidayaan yang ada pada masyarakat secara keseluruhan, karenanya hukum dipelajari sebagai produk dari interaksi sosial yang dipengaruhi oleh aspek-aspek kebudayaan, seperti ekonomi, politik, ideology, dan lain-lain. ${ }^{43}$ Pada kondisi lainnya bahwa hukum juga dipelajari sebagai proses sosial yang berlangsung dalam kondisi kehidupan masyarakat. ${ }^{44}$ Artinya, antropologi mempunyai porsi yang sangat kuat dalam memposisikan produk hukum dalam kondisi real masyarakat yang berbeda-beda, tujuannya tidak lain dan tidak bukan adalah bagaimana hukum bisa diterima dalam kehidupan dan kebudayaan masyarakat, sehingga hukum menjadi control kehidupan yang efektif dan efisien.

Pada dasarnya kajian tentang hak ijbar wali tidak dapat ditemukan dasarnya secara jelas di al-Qur'an ataupun hadis. Namun ada beberapa ayat yang memberikan isyarat atau petunjuk tidak langsung tentang hak ijbar wali, misalnya dalam surat al-Baqarah ayat 232. Dalam ayat tersebut dijelaskan bahwa bagi mantan istri yang telah ditalak oleh suaminya dan telah habis masa iddahnya, maka wali tidak boleh menghalangi mantan istri tersebut apabila ingin kembali pada suaminya. Meskipun ayat tersebut menjelaskan tentang hak wali terhadap janda, namun ada isyarat bahwa hak wali terhadap perawan dan janda berbeda. ${ }^{45}$

Fenomena hak ijbar yang dimiliki oleh wali pada zaman dimana peran wanita belum menonjol memiliki suatu posisi yang sangat penting dan dipercayai oleh lapisan masyarakat. Namun dalam perkembangan masyarakat Indonesia hari ini dengan diawali oleh R.A. Kartini dan isu gender kontemporer, perempuan seakan mempunyyai posisi yang sama dengan lakilaki dalam hal peran sosial. Dahulu perempuan kerja, keluar malam dianggap

\footnotetext{
${ }^{41}$ Suyono Suyono, "Hukum Keluarga:Perspektif Antropologi Hukum Islam," Jurnal Ilmiah AlSyir'ah 16, no. 1 (1 Agustus 2018): 52, https://doi.org/10.30984/jis.v16i1.647.

${ }_{42}$ Abuddin Nata, Metodologi Studi Islam (Jakarta: Raja Grafindo Persada, 2012), 35-38.

${ }^{43}$ Leopold Pospisil, Anthropology of Law: A Comparative Theory (London: Harper \& Row Plubisher, 1971), xx.

${ }^{44}$ Sally Folk Moore, Law as Process: An Anthropological Approach (Routlede and Kegan Paul, 1978), 1.

${ }^{45}$ Syaiful Hidayat, "Wali Nikah Dalam Perspektif Empat Madzhab," INOVATIF: Jurnal Penelitian Pendidikan, Agama Dan Kebudayaan 3, no. 2 (10 Februari 2017): 3.
} 
sesuatu yang tidak pantas, namun sekarang perempuan bekerja, bahkan keluar malam pun sudah menjadi peristiwa yang diiyakan oleh masyarakat.

Kemajuan teknologi dan ilmu pengetahuan telah banyak membawa dampak perubahan bagi kehidupan sosial dan kultur masyarakat, terutama kaum hawa. Jika dahulu peran perempuan terbatas hanya di dapur, sumur, dan kasur, serta budaya patriarki atau budaya yang menganggap bahwa kaum pria lebih superior dibanding kaum perempuan telah mengakar kuat di benak masyarakat, kini seiring dengan perubahan zaman dan semakin berkembang pesatnya alat komunikasi dan jendela informasi, perempuan sudah banyak ke luar rumah untuk belajar, bekerja, berorganisasi, berkarir, dan menunjukkan eksistensinya di dunia nyata. Tidak jarang pos-pos penting kemasyarakatan dan jabatan strategis dalam pemerintahan di tempati oleh kaum hawa. Akibatnya, mereka bertemu, berkenalan, dan berinteraksi dengan kaum laki-laki. Dari intensitas pertemuan itu, seringkali muncul benih-benih cinta yang dapat bersemi jika dipupuk dan disirami, serta sangat sulit untuk dibendung maupun dihindari. Cinta adalah sesuatu yang alami serta tidak bisa dipaksakan. Jika cinta dipaksakan maka biasanya tidak akan bertahan lama dan tidak berakhir bahagia.

Namun dalam perjalanannya, adanya hak ijbar bagi wali, seringkali menghalangi dan mengkandaskan jalinan cinta anak perempuannya dengan laki-laki yang dicintainya. Dengan cara menikahkan putrinya dengan laki-laki pilihan sang wali, akhirnya, sang putri pun dengan segala resikonya mengiyakan keputusan walinya, meskipun dia harus terpaksa dalam mengarungi kehidupan rumah tangganya. Akhirnya, hak ijbar menjadi suatu kuasa tersendiri bagi seorang wali, di mana perempuan menjadi obyek dalam pernikahan, bukan sebagai subyek hukum perkawinan. Praktik semacam ini, pasti mendatangkan suatu mafsadat layaknya sebagai nilai merah atas berlangsungnya hak ijbar. Praktik semaca ini pasti menimbulkan suatu mafsadat yaitu, keterpaksaan yang menjadi sebuah istilah "kawin paksa". Perkawinan yang memiliki implikasi dan tujuan untuk menciptakan keluarga bahagia, sakinah, mawaddah, dan rahmah, seakan diabaikan dengan berlangsungnya hak ijbar ini. Perempuan akan menjadi korban dari proses berkeluarga, kekerasan, keterkungkungan, ketidakbisaan berekspresi. Akhirnya, perkawinan bukan lagi menjadi suatu posisi yang di idam-idamkan, melainkan suatu yang menjadi momok besar untuk dihindari.

Dalam berbagai pendapat yang dikemukakan oleh para imam madzhab, penulis lebih condong pada pendapat Imam Hanafi yang manyatakan bahwa wali dilarang menikahkan anak perempuannya tanpa seizinnya, selama perempuan itu dewasa dan cakap hukum. Artinya, perempuan dewasa dipandang sudah mempunyai kecakapan dalam memilih pasangannya. Sehingga tidak selayaknya mendapatkan suatu keterpaksaan dalam hal pasangan. Pemaksaan dalam perkwinan bisa diklasifikasikan sebagai intervensi yang tidak beralasan, pelecehean terhadap perempuan, dan kekerasan yang berujung pada terjadinya kejahatan. ${ }^{46}$

\footnotetext{
${ }^{46}$ Khatidja Chantler, "Recognition of and Intervention in Forced Marriage as a Form of Violence and Abuse," Trauma, Violence \& Abuse 13, no. 3 (Juli 2012): 182, https://doi.org/10.1177/1524838012448121.
} 
Imam Syafii memiliki pendapat yang agak longgar dalam hal ini. Meskipun perempuan yang sudah dewasa dapat di ijbar oleh walinya, namun tetap harus dengan persetujuan si perempuan yang cukup dengan menggunakan isyarat diam. Hal tersebut berdasarkan hadis bahwa diamnya perawan merupakan tanda persetujuannya. Jadi ketentuan wali ijbar menurut ulama syafi'iyah tidak berlaku secara mutlak dan bebas. ${ }^{47}$

Dalam pandangan maqashid syari'ah, hak ijbar wali bertentangan dengan prinsip kemaslahatan. Dalam hal pelaksanaan hak ijbar (kawin paksa), tidak jarang dampak yang dihasilkan berupa mafsadat. Ketidak harmonisan, pertengkaran, bahkan berujung pada perceraian. hal ini, tentu bertentangan dengan maqashid (tujuan) perkawinan yakni, menciptakan keluarga bahagia. Salah satu tokoh maqashid syari'ah, Yusuf al-Qaradawi berpendapat bahwa wali tidak boleh memaksakan perkawinan anak perempuannya yang dewasa dan tidak cacat hukum untuk dinikahkan dengan laki-laki pilihan wali. Lebih jauh Yusuf al-Qaradawi mengomentari pendapat Imam Syafi'i yang memperbolehkan hak ijbar wali. Pendapatnya Imam Syafi'i didasarkan pada kondisi negaranya yaitu Mesir. Di Negara Mesir, perempuan jarang keluar rumah dan jarang berinteraksi dengan kaum laki-laki, sehingga perempuan kurang kemampuan untuk memahami kepribadian dan lebih mengenal lakilaki. Sebaliknya, jika saja Imam Syafi'i hidup pada kondisi hari ini, dimana perempuan banyak yang beraktifitas diluar rumah, berkarir, berpendidikan tinggi, bisa jadi Imam Syafi'i merubah pendapatnya, sebagaimana qoul qodim dirubah menjadi qoul jadid. ${ }^{48}$

Persoalan hak ijbar muncul pada era kontemporer yang memerlukan perhatian serius oleh umat Islam. ${ }^{49}$ Kondisi sekarang dipandang sebagai kondisi darurat untuk dilakukannya ijtihad dan model-model pendekatan baru dalam ijtihad, hal ini dimaksudkan untuk menghindar dari hal-hal yang menodai prinsip keadilan, prinsip maslahah, prinsip ketentraman, sesuai dengan kaidah maqashid: "Dar'ul mafasid muqaddamun 'ala jalbil mashalih" (menghindari dari yang membawa kerusakan didahulukan dari suau tindakan yang mendatangkan kemaslahatan). Artinya konsep semacam ini perlu mendapatkan suatu perombakan terhadap doktrin diskriminatif terhadap perempuan dalam ketentuan hak ijbar. Pada mulanya Tuhan tidak menginginkan suatu kesukaran, kesusahan yang ditanggung oleh hambaNya, inilah mengapa dalam pandangan maqashod syari'ah, hak ijbar wali bertentangan dengan prinsip-prinsip tujuan syari'at. ${ }^{50}$

Dalam karyanya, Maqashid Syari'ah, Abdul Hadi al-Fadli merekomendasikan dialektika dua pendekatan thariqahbunyaniyah (pendekatan struktural linguistik) dan thariqahbi'iyah (pendekatan sosio-historis kontekstual). ${ }^{51}$ Pendekatan dialektik-integratif yang dimaksud tidak hanya melibatkan ilmu-ilmu ke-Islaman, tetapi juga ilmu-ilmu lain yang relevan dan

\footnotetext{
${ }^{47}$ Hidayat, "Hak Ijbar Wali Nikah Dalam Kajian Historis Fiqh Shâfi'î," 7.

48 Yusuf Qardhawi, Al-Ijtihad al-Syari'ah al-Islamiyah (Cairo: Dar al-Qalam, 1999), 179.

49 Yusuf Qardhawi, Ijtihad Al-Mu'asirah Baina Al-Indibat Wa Al-Infirat, trans. oleh Abu Barzani (Surabaya: Risalah Gusti, 1995), 7-11.

${ }^{50}$ Imamul Muttaqin, "Studi Analisis Terhadap Pendapat KH. MA. Sahal Mahfud Tentang Wali Mujbir," Al-Hukama': The Indonesian Journal of Islamic Family Law 2, no. 1 (30 Juni 2012): 32-33.

${ }^{51}$ Abdul Jabbar Rifa'ah, Maqashid Syari'ah (Beirut: Dar al-Fikr, 2002), 217.
} 
turut membantu memperjelas hadirnya hukum Islam, seperti ilmu-ilmu humaniora, ilmu-ilmu eksakta dan sebagainya. Untuk itu mujtahid kontemporer harus memiliki tiga dimensi kesadaran yakni kesadaran historis (al-wa'yu altarikhiy), kesadaran teoristis (al-wa'yu al-nadzariy) dan kesadaran realistis-praktis (al-wa'yu al-'amaliy). ${ }^{52}$ Dengan kesadaran historis, seorang mujtahid harus memahami substansi dari kronologi lahirnya teks dan dapat menangkap pesan di balik teks. Kesadaran ini mengantarkan mujtahid pada pentingnya ilmu sosiologi dan antropologi hukum dan sejarah hukum sebagai pendekatan. Karena hakikatnya hukum lahir dipengaruhi oleh historitas dan kontruksi sosial masyarakat. Sedangkan kesadaran teoritis menyadarkan mujtahid untuk memiliki keilmuan yang multidisiplin, bukan monodisiplin. Karena teks-teks hukum tidak dapat dipisahkan dari teks-teks lainnya seperti teks sosial, teks budaya dan sebagainya. Dengan demikian, mujtahid kontemporer hendaknya mampu mendialektikan pendekatan klasik (clasiccal approaches) dan pendekatan kontemporer (contemporary approaches) dengan berbasis maqasid hukum. Pada gilirannya kesadaran kontekstual pun harus menjadi acuan politik mujtahid agar tidak terjadi kekosongan hukum. Sebab teks sendiri tak ubahnya hasil rekam konteks masa lalu yang harus dibaca untuk konteks sekarang.

Konsepsi diatas sangat relevan jika disandingkan dengan keniscayaan penggunaan pendekatan antropologi hukum Islam dalam pembentukan hukum, dalam hal ini, mengenai hak ijbar. Pendekatan antropologi hukum Islam diperlukan dalam ketentuan hukum hak ijbar dikarenakan bersangkutan dengan nilai-nilai kemanusiaan, kepatutan, dan budaya. Salah satu yang menjadi sorotan dalam konteks pelaksaan hak ijbar, perempuan yang menjadi objek kajian ini mengalami perbedadaan kebiasaan dan kebudayaan dalam konteks historis hukum. Pada masa lampau, perempuan diidentikan dengan ketertutupan dan keterbatasan.

Kajian agama khususnya bab wali ijbar haruslah dipandang adri berbagai sudut keilmuan, baik sosiologi, antropologi ataupun psikologi. Suatu norma agama harus bersentuhan dengan aspek realitas supaya agama tidak hanya dianggap sebagi sumber yang kaku dan rigid. Begitu pula kajian wali ijbar harus dipahami dari berbagai sudut pandang keilmuan. Sehingga aturan agama tidak terjebak pada pendekatan filosofis-teologis yang justru menjauhkan agama dari yang membutuhkannya, yakni realitas manusia. ${ }^{53}$

Antropogi hukum Islam menjadi suatu bagian disiplin keilmuan pada term empiris, oleh karrenanya ilmu anttropologi memperlihatkan sebuah potret dan fakta hukum yang ada di masyarakat tertentu, khususnya terhadap fenomena dan praktik hak ijbar. Kajian ini sedikit bergeser pada kajian hukum normative yang cenderung menfokuskan pada berbagai aspek dan peraturan perundang-undangan. Dalam antropologi hukum Islam memandang bahwa perkawinan sebagai upaya pelebbaran menyamping tali ikatan antara dua kelompok himpunan yang tidak ada ikatan saudara atau dalam satu kelompok endogen bersama. Dalam pemahaman masyarakat secara umum bahwa

\footnotetext{
${ }^{52}$ Hasan Hanafi, Al-Nash ila al-Waqi' (Cairo: Markaz Al Kitab, 2005), 55.

${ }^{53}$ Abu Bakar, "Kawin Paksa (Sebuah Hegemoni Laki-Laki Atas Perempuan)," Al-Ihkam: Jurnal Hukum Dan Pranata Sosial 8, no. 1 (14 Oktober 2014): 4, https://doi.org/10.19105/alihkam.v8i1.341.
} 
perkawinan ini merupakan transaksi antara dua belah pihak unttuk melegalkan suatu hubungan tertentu.

Dalam konteks antropologi, praktik perkawinan yang dalam hal ini praktik hak ijbar mempunyai praktik dan doktrin khusus pada kondisi dan sosio kultur yang ada pada masayarakat tertentu. Indonesia yang mempunyai ciri khas khusus dalam bermadzhab dan dominan pada madzhab syafi'i. Hal ini tentu Indonesia lebih cocok jika menggunakan madzhab syafi'i. Namun dalam hal ketentuan hak ijbar, madzhab syafi'i cenderung berorientasi pada porsi khusus pada wali. Berbeda dengan madzhab hanafi yang memberikan porsi rasionalitas dalam ketentuan hak ijbar. Dalam praktik masyarakat Indonesia yang condong terhadap madzhab syafi'i, namun dalam ketentuan mengenai hak ijbar mengalami pertentangan dan perdebatan dalam praktik kehidupan masyarakat. Jika ditelusuri dalam konteks historis, hadis Nabi tentang meminta izin kepada anak perempuan ini merupakan hadis yang shahih. Selain hal tersebut, dalam hal sejarah menunjukkan bahwa Rasulullah dan Fatimah pernah berdiskusi dengan tujuan menyepakati simbol atau isyarat yang dipergnakan dalam menunjukkan persetujuan. ${ }^{54}$

Dalam kajian mengenai hak ijbar yang merupakan term kajian hukum islam, dimana hukum islam berfungsi sebagai social control dan social engineering. Fungsi ini berguna dalam term lokalitas dalam teoritisasi hukum untuk berdialog dengan budya hukum. Dalam pendekatan antropoligi hukum Islam, ketentuan mengenai hak ijbar diperlukan adaptasi terhadap budaya dan kondisi lokalitas Negara Indonesia. Pendekatan ini bertujuan untuk mengimplementasikan hukum Islam kedalam sholih fi kulli makan wa zaman (beradaptasi dalam perkembangan tempat dan waktu).

Seiring dengan perkembangan peradaban, kebudayaan dan perubahan sosial yang terus bergerak pada ranah globalisasi, peran kaum perempuan semacam itu agaknya sudah jauh mengalami pergeseran. Asumsi ini diperkuat dengan gencarnya perjuangan kaum perempuan dalam upaya melakukan pembebasan terhadap mitos lama, emansipasi wanita, dan kesetaraan gender. Saat ini perempuan telah terlibat aktif dalam membangun bangsa dan negara melalui dunia politik, ekonomi, sosial, budaya, pendidikan, bahkan keamanan. Kini wilayah-wilayah tersebut tidak hanya didominasi oleh kaum pria, wanita pun turut andil di dalamnya. Bahkan kadang kaum wanita bisa tampil lebih mandiri, dinamis, kreatif, penuh inisiatif, dan profesional dalam mengambil perannya tersebut.

Problem semacam ini mungkin tidak pernah ditemukan pada masa ulama' klasik. Perbedaan tempat, kondisi budaya, menjadi pondasi utama dalam ketentuan hak ijbar ini. Artinya, ketentuan hak ijbar adalah produk dari tradisi dan budaya, dalam perspektif antropologi hukum Islam, hak ijbar hari ini sangat bertentangan dengan nilai-nilai sosial, nilai-nilai kepatutan, serta nilai-nilai budaya, serta norma-norma yang ada. Atas dasar inilah, kajian terhadap hukum Islam dalam perspektif antropologi dan sosiologi juga psikologi meruakan sebuah keharusan. Bukan bermaksud hanya bersentuhan

\footnotetext{
${ }^{54}$ Ramadhita Ramadhita, "Latar Historis Indikator Kerelaan Perempuan Dalam Perkawinan," De Jure: Jurnal Hukum dan Syar'iah 7, no. 1 (21 Juni 2016): 38, https://doi.org/10.18860/jfsh.v7i1.3507.
} 
dengan kondisi dan realitas doktrin hukum Islam yang dianggap sebagai kebenaran mutlak, melainkan lebih pada sebuah upaya membumikan produk hukum Islam, sehingga tidak terkesan kaku dan riqid. Selain itu, menempatkan hukum Islam sebagai kontruksi dalamsegi normative seringkali dihalangi oleh pendekatan filosofis-teologis yang justru akan menjauhkan hukum islam produk hukum islam dari kondisi dan realitas sossial.

\section{Kesimpulan}

Ketentuan mengenai hak ijbar yang dimiliki oleh wali dalam fiqh munakahah, menurut pandangan ulama' madzhab ada beberapa perbedaan, ada yang melegalkan dengan tanpa seizin anak perempuan, ada yang melarang bagi yang mempunyai anak perempuan dewasa dan mempunyai kecakapan berbuat hukum. Namun dalam perjalanannya, umat Islam seakan terdoktrin bahwa hak ijbar merupakan hak yang boleh diambil, yakni sang wali bisa memaksa anaknya menikah tanpa seizin yang bersangkutan. Dalam perspektif maqashid syari'ah yang mempunyai dimensi menciptakan kemaslahatan, perdamaian, ketentraman, serta keadilan, baik dalam tingkat diri pribadi maupun dalam konteks maslahah al-'ammah, ketika digunakan pisau analisis dan pendekatan hukum terhadap ketentuan hak ijbar, tentu sangat bertentangan dikarenakan pelaksanaan hak ijbar dominan pada penciptaan mafsadat yang menjadi kebalikan dari penciptaan maslahah, dikarenakan pelaksanaan hak ijbar dimungkinkan adanya keterpaksaan, sehingga membuat pernikahan tidak harmonis.

Dalam perspektif antropologi hukum Islam yang mempunyai porsi lebih dalam penciptaan hukum dan keberlangsungan eksistensi hukum, juga mempunyai cara pandang yang kontradiktif terhadap keberlangsungan ketentuan tentang hak ijbar wali. Nilai-nilai, norma-norma, serta budaya masyarakat hari ini telah memberikan posisi lebih terhadap determinasi kaum perempuan. Artinya, eksistensi dan peran perempuan hari ini sangat dibutuhkan. Dengan demikian, ketentuan hak ijbar yang memberikan pengekangan terhadap kaum perempuan sangat bertentangan dengan nilainilai, norma-norma, dan budaya yang ada pada masyarakat hari ini. Wal hasil, hak ijbar tidak bisa diterima oleh berbagai lapisan masyarakat.

\section{Daftar Pustaka}

Abdillah, Mujiyono. Dialektika Hukum Islam Dan Perubahan Sosial: Sebuah Refleksi Sosiologis Atas Pemikiran Ibn Qayyim Al-Jauziyyah. Surakarta: Muhammadiyah University Press, 2003.

Atabik, Ahmad, dan Khoridatul Mudhiiah. "Pernikahan Dan Hikmahnya Perspektif Hukum Islam." YUDISIA : Jurnal Pemikiran Hukum dan Hukum Islam 5, no. 2 (2014).

Aziz, Safrudin. "Tradisi Pernikahan Adat Jawa Keraton Membentuk Keluarga Sakinah." IBDA : Jurnal Kajian Islam dan Budaya 15, no. 1 (2 Mei 2017): 22-41. https://doi.org/10.24090/ibda.v15i1.724.

Azizy, Ahmad Qadri Abdillah. Melawan Globalisasi: Reinterpretasi Ajaran Islam Persiapan SDM dan Terciptanya Masyarakat Madani. Yogyakarta: Pustaka Pelajar, 2003. 
Bakar, Abu. "Kawin Paksa (Sebuah Hegemoni Laki-Laki Atas Perempuan)." AlIhkam: Jurnal Hukum Dan Pranata Sosial 8, no. 1 (14 Oktober 2014): 69-85. https://doi.org/10.19105/al-ihkam.v8i1.341.

Bisri, Cik Hasan. Model Penelitian Figh Jilid 1: Paradigma Penelitian Fiqh Dan Fiqh Penelitian. Jakarta: Kencana, 2003.

Chantler, Khatidja. "Recognition of and Intervention in Forced Marriage as a Form of Violence and Abuse." Trauma, Violence \& Abuse 13, no. 3 (Juli 2012): 176-83. https://doi.org/10.1177/1524838012448121.

Daliyo, J.B. Pengantar ilmu hukum. Jakarta: Gramedia, 2009.

Daroini, Fathi al-. Al-Manahij al-Ushuliyyah fi Ijtihad bi al-Ra'yi fi al-Tasyri'. Damaskus: Dar al-Kitab al-Hadis, 1975.

Hakim, Muhammad Lutfi. "Rekonstruksi Hak Ijbar Wali: Aplikasi Teori Perubahan Hukum dan Sosial Ibn al-Qayyim Al-Jawziyyah." Al-Manahij: Jurnal Kajian Hukum Islam 8, no. 1 (2014): 45-56. https://doi.org/10.24090/mnh.v8i1.401.

Hanafi, Hasan. Al-Nash ila al-Waqi'. Cairo: Markaz Al Kitab, 2005.

Haq, Husnul. "Reformulasi Hak Ijbar Fiqhi Dalam Tantangan Isu Gender Kontemporer." PALASTREN Jurnal Studi Gender 8, no. 1 (30 Maret 2016): 197-224. https://doi.org/10.21043/palastren.v8i1.941.

Hidayat, Syaiful. "Hak Ijbar Wali Nikah Dalam Kajian Historis Fiqh Shâfi'î." Tafáqquh: Jurnal Penelitian Dan Kajian Keislaman 3, no. 1 (1 Juni 2015): 0113.

- "Wali Nikah Dalam Perspektif Empat Madzhab." INOVATIF: Jurnal Penelitian Pendidikan, Agama Dan Kebudayaan 3, no. 2 (10 Februari 2017): 98124.

Ibnu Rusyd. Bidayah al-Mujtahid wa Nihayah al-Muqtashid. Vol. 2. Beirut: Dar alFikr, 2005.

Izzati, Arini Rabbi. "Kuasa Hak Ijbar Terhadap Anak Perempuan Perspektif Fiqh dan HAM." Al-Mawarid: Jurnal Hukum Islam 11, no. 2 (2011).

Khaeruman, Badri. "Al-Qaradawi Dan Orientasi Pemikiran Hukum Islam Untuk Menjawab Tuntutan Perubahan Sosial." Wawasan: Jurnal Ilmiah Agama Dan Sosial Budaya 1, no. 2 (15 November 2016): 227-38. https://doi.org/10.15575/jw.v1i2.740.

Khin, Mushtafa al-, Musthafa al-Bugha, dan Ali al-Syarbaji. Al-Fiqh al-Manhaji 'ala madzhabi al-Imam al-Syafi'i. Damaskus: Dar al-Qalam, 2005.

Mahkamah Agung RI. Laporan Tahunan Mahkamah Agung Republik Indonesia Tahun 2017. Jakarta: Mahkamah Agung, 2018.

—. Laporan Tahunan Mahkamah Agung Republik Indonesia Tahun 2018: Era Baru Peradilan Modern Berbasis Teknologi Informasi. Jakarta: Mahkamah Agung, 2019.

Mahsun, Mahsun. "Wali Mujbir Dalam Pusaran Pemikiran KH. MA. Sahal Mahfudh." Al-Mabsut: Jurnal Studi Islam dan Sosial 8, no. 1 (1 April 2014): 944.

Maimun, Maimun, Mohammad Toha, dan Misbahul Arifin. "Fenomena Tingginya Angka Cerai-Gugat Dan Faktor Penyebabnya: Analisis Reflektif Atas Kasus-Kasus Perceraian Di Madura." Islamuna: Jurnal Studi Islam 5, no. 2 (12 April 2019): https://doi.org/10.19105/islamuna.v5i2.2105. 
118 | De Jure: Jurnal Hukum dan Syar'iah, Vol. 12 No. 1 Tahun 2020

Mas'ud, Muhammad Khalid. Filsafat Hukum Islam Dan Perubahan Sosial. Diterjemahkan oleh Yudian W. Aswin. Surabaya: Al-Ikhlas, 1987.

Mas'udi, Masdar Farid. "Meletakkan Kembali Mashlahah sebagai Acuan Syari'at." Ulumul Qur'an 6, no. 3 (1995).

Moore, Sally Folk. Law as Process: An Anthropological Approach. Routlede and Kegan Paul, 1978.

Muhammad Amin Abdullah. "Relevansi Studi Agama dalam Milenium Ketiga." Dalam Mencari Islam: Studi Islam Dengan Berbagai Pendekatan, disunting oleh Muhammad Amin Abdullah dkk. Yogya: Tiara Wacana, 2000.

Muttaqin, Imamul. "Studi Analisis Terhadap Pendapat KH. MA. Sahal Mahfud Tentang Wali Mujbir." Al-Hukama' : The Indonesian Journal of Islamic Family Law 2, no. 1 (30 Juni 2012): 19-36.

Muttaqin, Muhammad Ngizzul, dan Iffatin Nur. "Menelusuri Jejak Maqashid Syari'ah Dalam Istinbath Hukum Imam Hambali." Ahkam: Jurnal Hukum Islam 7, no. 1 (1 Juli 2019): 143-168-168. https://doi.org/10.21274/ahkam.2019.7.1.143-168.

Najwah, Nurun. "Kriteria Memilih Pasangan Hidup (Kajian Hermeneutika Hadis)." Jurnal Studi Ilmu-Ilmu Al-Qur'an Dan Hadis 17, no. 1 (8 Mei 2018): 95-120. https://doi.org/10.14421/qh.2016.1701-05.

Nata, Abuddin. Metodologi Studi Islam. Jakarta: Raja Grafindo Persada, 2012.

Pospisil, Leopold. Anthropology of Law: A Comparative Theory. London: Harper \& Row Plubisher, 1971.

Qardhawi, Yusuf. Al-Ijtihad al-Syari'ah al-Islamiyah. Cairo: Dar al-Qalam, 1999.

—. Ijtihad Al-Mu'asirah Baina Al-Indibat Wa Al-Infirat. Diterjemahkan oleh Abu Barzani. Surabaya: Risalah Gusti, 1995.

Rais, Isnawati. "Tingginya Angka Cerai Gugat (khulu') Di Indonesia: Anlisis Kritis Terhadap Penyebab Dan Altternatif Solusi Mengatasi." Al-Adalah 12, no. 1 (Juni 2014).

Ramadhita, Ramadhita. "Latar Historis Indikator Kerelaan Perempuan Dalam Perkawinan." De Jure: Jurnal Hukum dan Syar'iah 7, no. 1 (21 Juni 2016): 31. https://doi.org/10.18860/j-fsh.v7i1.3507.

Raysuni, Ahmad al-. Nazhariyat al-Maqashid 'Inda al-Imam al-Syathibi. Riyadh: alDar al-'Alamiyah li al-Kitab al-Islami wa al-Ma'had al-'Alami al-Fikr alIslami, 1981.

Rifa'ah, Abdul Jabbar. Maqashid Syari'ah. Beirut: Dar al-Fikr, 2002.

Rippin, Andrew. Muslims: their religious beliefs and practices. 4th ed. The library of religious beliefs and practices. New York: Routledge, 2011.

Saebani, Beni Ahmad, dan Encup Supriatna. Antropologi Hukum. Bandung: CV Pustaka Setia, 2012.

Suardiman. "Kehidupan Perkawinan Bahagia: Dampak Positif Untuk Keseimbangan Mental Anak Kini Dan Nanti." Buletin Psikologi 6, no. 2 (23 September 2015). https://doi.org/10.22146/bpsi.7397.

Sumanto, Dedi. "Hukum Adat Di Indonesia Perspektif Sosiologi Dan Antropologi Hukum Islam.” JURIS (Jurnal Ilmiah Syariah) 17, no. 2 (31 Desember 2018): 181-91. https://doi.org/10.31958/juris.v17i2.1163.

Suyono, Suyono. "Hukum Keluarga:Perspektif Antropologi Hukum Islam." Jurnal Ilmiah Al-Syir'ah 16, no. 1 (1 Agustus 2018): 58-73. https://doi.org/10.30984/jis.v16i1.647. 
Syarifuddin, Amir. Hukum Perkawinan Islam Di Indonesia: Antara Fiqh Munakahat Dan Undang-Undang Perkawinan. Jakarta: Kencana, 2006.

Ulwan, Abdullah Nashih. Islam Syariat Abadi. Diterjemahkan oleh Daud Rashid. Jakarta: Usamah Press, 1992.

Yafie, Ali. "Posisi Ijtihad dalam Keutuhan Ajaran Islam." Dalam Ijtihad dalam sorotan, disunting oleh Jalaluddin Rahmat. Bandung: Mizan, 1994.

Zahrah, Abu. Ushul Fiqh al-Islam. Vol. II. Beirut: Dar al-Fikr al-Muassir, 1986.

Zuhaili, Wahbah al-. al-Fiqh al-Islami wa Adillatuh. Damaskus: Dar al Fikr, 2003. 